\title{
THE ECONOMIC DIMENSION OF THE INFLUENCE OF SECTORAL EXEMPTIONS ON THE DYNAMICS OF THE DIFFERENTIATION OF THE PRICES OF ORIGINAL SPARE PARTS FOR ENGINE VEHICLES IN POLAND
}

Data przesłania: 12.02.2017 | Data akceptacji: 04.06.2017 | JEL: L11, L51, L91, L51, L62, R40, R49

\section{Wojciech Lewicki}

Zachodniopomorski Uniwersytet Ekonomiczny w Szczecinie wojciech.lewicki@zut.edu.pl

\begin{abstract}
The article presents the considerations concerning the impact of legal regulations in the form of sectoral exemptions on the dynamics of the price differentiation of original spare parts for motor vehicles in Poland. In order to present the economic dimension of the research problem, the case study was used - a numerical experiment consisting of the change analysis of prices of the strictly selected spare parts from the rime of introducing the mentioned legal regulations, until 2017. The intention of the article is to draw attention to the essence of the research issue by demonstrating that the introduction of EU sectoral exemptions, in spite of the improved market competitiveness in the form of the increased availability to other categories of parts, in most cases did not lead to a significant price reduction of new original components on the Polish market of spare parts.

KEYWORDS the economics of transport, EU politics, sector exemptions, legal aspects of transport, prices of the spare parts, costs of repairs, operation
\end{abstract}

\section{INTRODUCTION}

As indicated by the available literature on economics, competition policy is one of the major and earliest agreed community policies. The legitimacy and necessity of it is indirectly related to one of the fundamental aims of the European Communities, namely the creation of a common market of the Member States. The competition policy is intended to guarantee that barriers abolished in internal trade, within the common market, will not be replaced by other actions by businesses or governments, leading to distortions of competition (Burda, Wyplosz, 2013). It should be noted at the outset that, before the introduction of sectoral exclusions on the automotive market in the European Union, there were certain restrictions in the competition, among others, in relation to sales of spare parts. One of the fundamental objectives of implementing sectoral exemptions 
in 2003 in the EU automotive market was to provide consumers with an easy access to, inter alia, goods in the form of different categories of spare parts, at very similar prices (Commission Regulation, 2002).

The available literature on transport economics promotes the view that the increase in market availability to other categories of parts has led to a significant decline in prices of new original spare parts, resulting in a significant reduction of total repair costs (Szymonik, 2013).

The above-presented concept is based on the belief that, in the current market environment, the vehicle user, due to the implementation of common legal regulations in the form of sectoral exemptions, can apply up to four categories of parts with different quality and price parameters during repair, which provides the basis for identifying potential economic benefits by all users of motor vehicles in Poland. So, in the light of academic considerations, the question arises as to whether the notion promoted in the literature is fully confirmed in the market reality? Thus, in the context of the European Commission's decision to extend the duration of the regulation in question to 2023, the problem of dynamics of the price differentiation of original spare parts undoubtedly constitutes an important research problem. In particular that the repair of a newly purchased vehicle covered by a manufacturer's warranty can only be carried out using new original parts (Burnewicz, 2005). In addition, the available literature of the transport economics has no such analyses and studies in the interdisciplinary sense, which justifies the legitimacy of undertaking this research topic even more.

The presented approach has become the basis for the adoption of boundary conditions and the conduct methodology aimed at measuring the economic determinants of the impact of sectoral exemptions on the dynamics of differentiation of prices of original spare parts for passenger cars in Poland by:

1. Characterising the essence of the impact of sectoral exemptions on the increase in competitiveness and availability of particular categories of spare parts on the Polish automotive market.

2. The analysis of prices of the strictly selected spare parts in relation to particular vehicle models from the selected market segment.

The intention of the article is to draw attention to the essence of the research issue by demonstrating that the introduction of EU sectoral exemptions, in spite of the improved market competitiveness in the form of the increased availability to other categories of parts, in most cases did not lead to a significant price reduction of new original components on the Polish market of spare parts.

\section{THE ESSENCE OF THE IMPACT OF SECTORAL EXEMPTIONS ON THE SPARE PARTS MARKET}

According to Article 81 of the Treaty on the European Community, agreements between companies or enterprises, which lead to noticeable restriction of competition, are prohibited. On this basis, the European Commission has adopted the so-called sectoral exemption regulations detailing the conditions, which should meet certain categories of agreements in general sectors, as well as in more details, including in the automotive sector (Zucke, De Stefano, 2010). As indicated by the available literature, sectoral exemptions are agreements made between two or more entrepreneurs operating at different turnover levels, who intend to, among others, purchase, sell or resell spare parts for motor vehicles (Colino, 2010). 
Until the sectoral exemptions entered into force in 2003, no automotive regulation contained a clear definition of the "original part". The concept of the "original part" has functioned based on common habits and customs, and has been reserved only for those elements, which were purchased in the authorised network of the car manufacturer and in the packaging with his logo (Creutzig, 2003). Only such items could be sold and installed in authorised service stations, and the use of others would mean a loss of warranty. In the international automotive jargon they were identified with the "OE" symbol, from English "Original Equipment". According to the motor vehicle manufacturers, all other parts on the market were "non-original parts", and their use was allowed only outside the authorised network of the given car brand. This "non-original" market sector was referred to as the "after-market" in the international jargon. The non-original parts, especially the so-called unoriginal ones, were referred to as "replacements" or "fakes" on the Polish automotive market (Lewicki, 2014).

However, the division into "original" and "non-original" parts have not only been insufficiently legally binding, but it also has not been so clear, as it might seem. The problem is due to the fact that as much as $80 \%$ of spare parts on the market come from independent manufacturers of parts, and only $20 \%$ is delivered directly by the car manufacturers. Independent manufacturers of spare parts direct $43 \%$ of their production to the first assembly of vehicles (Kaliszuk, Ambroziak, Błaszuk-Zawiła, Kozłowski, 2011). The remaining production of spare parts, 37\%, is intended for sale on the secondary market by independent distributors. These manufacturers sometimes have contractual rights to parallel sales of the same products in their own distribution networks, and then at the same time they appear on the market in the manufacturer's packaging (Stan branż..., 2013). This is best seen on the example of headlamps, on which manufacturers have been putting their logos for years, thus significantly improving their recognition on the market, like for example Bosch, Hella, Magneti-Marelli or Valeo.

Taking into account definitions and legal regulations concerning the rules of using spare parts, and interpretations, which were included in the official document (Rozporządzenie, 2010), and the available literature of the subject (Lewicki, 2014), the division into four fundamental categories of spare parts was adopted:

- original spare parts,

- other original spare parts,

- non-original spare parts - replacements,

- spare parts of comparable quality.

Original spare parts provided by the vehicle manufacturer, are most often labelled as OR in the subject literature and on the Internet (and as O, Q1). Such parts have original packaging of the vehicle manufacturer bearing its logo. Although $4 / 5$ of all such parts of vehicle manufacturers are ordered from external suppliers, they are responsible for their quality, technical and technological specification, and distribution. Therefore, the legislator agrees that the vehicle manufacturers may require the use of this category of parts, when the vehicle repair is performed at an authorised repair station.

Original spare parts from a third undertaking as most often labelled as OEM in the subject literature and on the Internet (and as Q, Q2). The EU Regulation has extended the concept of "original spare parts" to all components that have the same quality and are manufactured according to the same specifications as parts distributed by vehicle manufacturers themselves. This mainly 
applied to all parts coming directly from the so-called "suppliers for the first assembly, such as Bosch, Delphi, Hella, Magneti-Marelli, Pikington, Valeo etc.

Non-original spare parts, so-called "replacements" are most often designated as AM (and as Z, Q3) ("after market"). This group can be defined as all parts, which were not included neither to "original parts" nor "parts of a comparable quality" by the regulation.

Spare parts of a comparable quality. There is no established designation in the literature, so the OEQ designation was proposed (along with P, Q4). The EU regulation has identified this new category of parts from all "replacements", which correspond to the elements distributed by the vehicle manufacturers in terms of quality, but without the obligation to use identical technical and technological specifications during their manufacturing and so, e.g. the material from which the given element was made does not have to be the same.

At this stage of considerations, it should be mentioned that there are also two other fundamental categories of spare parts available on the Polish automotive market, not defined by the regulations mentioned, namely:

- regenerated parts,

- used parts.

Regenerated parts are designated with the WR abbreviation in the literature (Zieliński, 2008). Currently, a significant number of components and parts removed from the vehicles of the given brand is suitable for regeneration and re-use. However, it is important to stipulate that this process in most cases applies only to original parts. Regeneration of these parts is carried out within the verified technological process developed by individual manufacturers of the given vehicles. Original regenerated parts allow both operating and post-collision repairs at much lower costs. As indicated by the available reports and studies on the Polish market, the prices of original components subjected to the regeneration process may be even up to 60 percent lower in relation to their new equivalents (Abramek, Uzdowski, 2012). In addition, some authors claim in the available literature that regenerated parts, apart from the lower price, do not differ in quality from brand new elements, and the quality and period of the manufacturer's warranty is the same as of the brand new ones and usually amount up to two years (Zieliński, 2008).

Used parts are defined with the $U$ symbol. High availability on the market and a large price range makes them especially attractive for vehicle models with a shorter service life. While their durability and origin may evoke some concerns. In most cases, these parts have been removed from vehicles that have suffered severe collisions and road accidents, so the assessment of their technical and quality parameters may be significantly impeded (Nowak, 2004).

At this stage of considerations it is worth emphasising that the aspect of shaping the prices of original parts on the contemporary automotive market is an issue of a fundamental economic importance both for the individual client and for the company with a significant fleet of vehicles. On the other hand, these legal regulations have enabled the "revolutionary" law to use other spare parts than the original ones for operating repairs. However, on the other hand, they have created grounds for undertaking discussion or the increase of competitiveness in the form of the emergence of other categories of spare parts on the market has in reality led to the reduction of prices for new original spare parts.

Summarizing the present issues, taking into account only the theoretical aspect of the economic dimension of the impact of sectoral exemptions on the dynamics of differentiation of original 
spare parts for passenger cars in Poland, it can be mistakenly concluded that the increase in market availability to other categories of spare parts has led directly to a considerable reduction of their prices. Meanwhile, the research presented below illustrates the actual trends in terms of shaping of the prices of original parts for passenger cars on the Polish automotive market.

\section{ANALYSIS OF THE DYNAMICS OF DIFFERENTIATION OF PRICES OF ORIGINAL PARTS IN PARTICULAR YEARS}

The complexity of the research problem, and the continuous and ongoing play of demand and supply shaping the prices of original spare parts on the Polish automotive market required an experimental approach from the author. Therefore, the author has used the preconceived patterns of behaviour in his simulations, in order to show the relevant relationships. Therefore, the analysis of the market availability of all spare parts available on the Polish market will not be the subject of further considerations, only the dynamics of price changes of the strictly selected spare parts will be presented based on the specific market segment. In addition, for simplicity of the author's simulations it was assumed that the analysis of dynamics of price changes will cover the years from 2003 to 2017, which will allow to identify the impact of sectoral exemptions on the shaping of prices of original prices on the Polish automotive market.

At the very beginning, in order to keep the logical correctness and methodological value of the research, it was assumed that:

1. Each vehicle selected for the studies was subject to the individual repair process provided for by the particular vehicle manufacturer.

2. The scope of research covered the passenger cars from the market B segment. Four models of vehicles were selected for the analysis with specific characteristics and design. The selected vehicles were characterised by a significant popularity among the clients and the highest number of copies sold in the years 2003-2017 on the Polish market (car sales 2017).

3. Taking into account the scope of hypothetical vehicle repairs, it was assumed that the analysis of prices will be applied to four strictly selected spare parts, which are most often damaged in the event of road collisions, that is: front bumper, front left light, front left fender, engine compartment cover (Nowak, 2004).

4. In order to estimate the dynamics of changes in spare parts prices, a specialised expert tool, Eurotax program, was used, supporting the numerical experiment with a cost estimation method. This is currently the only method to obtain information about actual archival cen spare parts on the Polish market (Instrukcja program Eurotax, 2017).

5. In all simulations, in order to maintain the methodological correctness of the research, it was assumed that the analysis will apply only to new original parts.

6. From the point of operation and the possibility of capturing the necessary data, the results of the numerical experiment were presented in the resulting form in the relevant figures from 1 to 4 . 


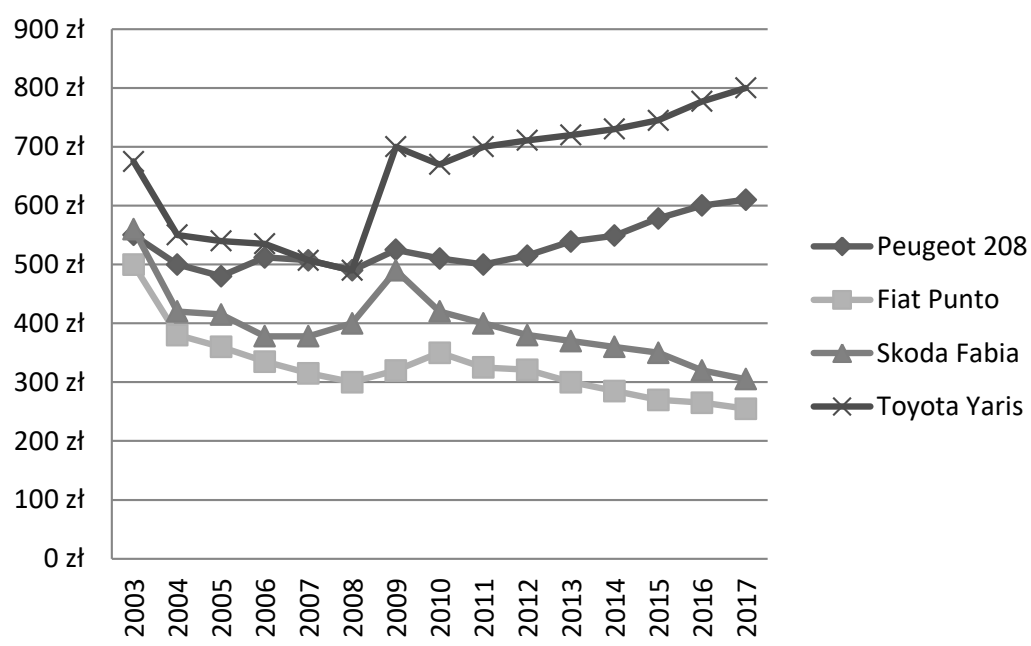

Figure 1. Analysis of the dynamics of the price formation of original spare parts on the example of the front headlight for vehicles from segment $B$

Source: own study.

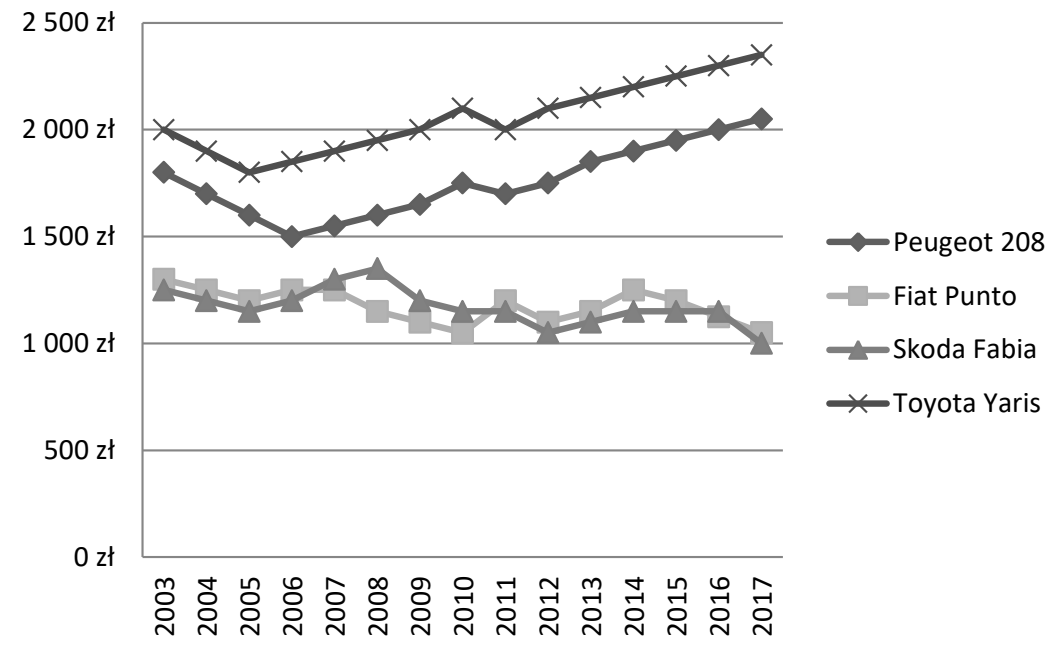

Figure 2. Analysis of the dynamics of the price formation of original spare parts on the example of the front bumper for vehicles from segment $B$

Source: own study. 


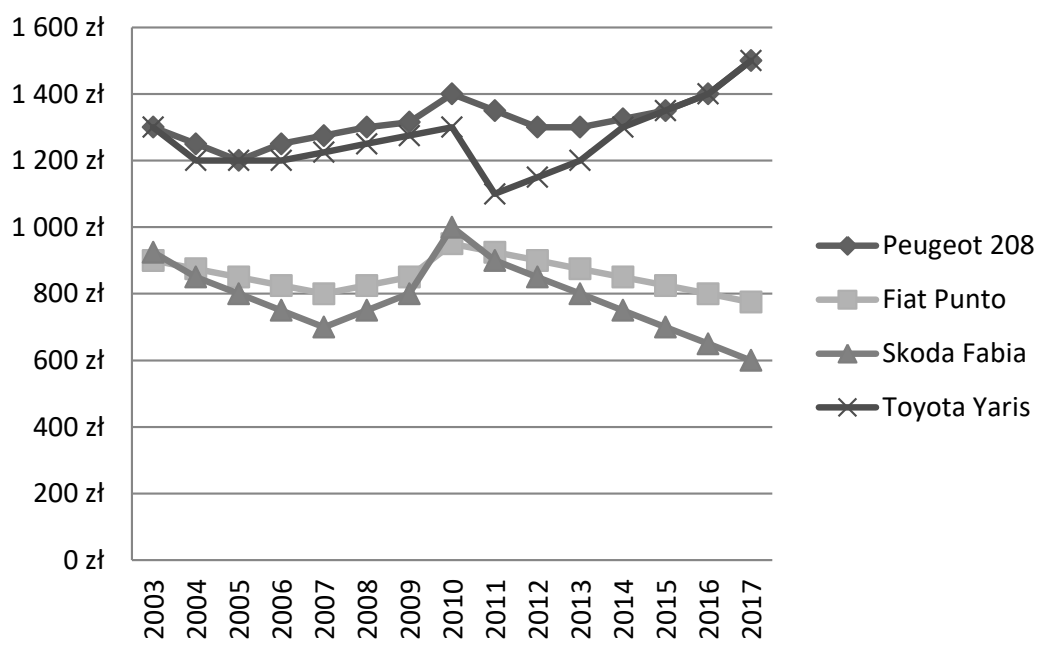

Figure 3. Analysis of the dynamics of the price formation of original spare parts on the example of the front fender for vehicles from segment $B$

Source: own study.

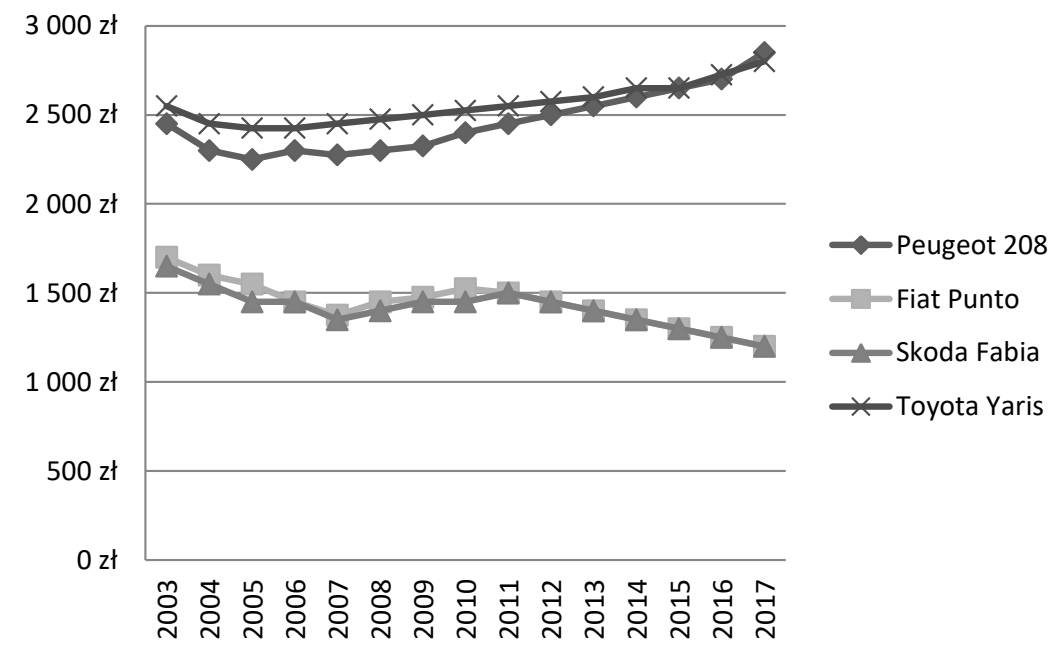

Figure 4. Analysis of the dynamics of the price formation of original spare parts on the example of the engine compartment cover for vehicles from segment $B$

Source: own study. 
The cumulative analysis of the data presented in figures from 1 to 4 indicates significant changes in the dynamics of price differentiation of original parts in the analysed period of time. The interpretation of the results of the author's research showed that a significant price reduction occurred at the turn of 2004. According to the author, the direct cause of this phenomenon was the introduction of regulations in the form of sectoral exemptions on the Polish automotive market. This trend has been observed for all vehicle manufacturers analysed from the selected market segment. It is worth noting that despite the increase in the market availability to other categories of spare parts in subsequent years, their systematic increase in prices has been observed. The highest values were in 2010. The motives for these actions could have included the uncertainty of the manufacturers regarding the extension of the Regulation for subsequent years. In addition, data analysis indicated that after 2010 some manufacturers, such as Toyota and Peugeot, have decided to gradually increase the price of their parts, the value of which in 2017 exceeds the one from 2010. On the basis of observations of the market reality, the author of the paper argues that the effect on such a situation was due to the low market availability to alternative parts, in case of these particular vehicle models. Thus, the quality strategy model was used in relation to the sale of these parts. While in case of Fiat and Skoda models, a considerable price reduction of spare parts was stated, also in the period from 2010 to 2017. These manufacturers have used the price strategy as a means of achieving the market objectives for the sale of spare parts.

\section{SUMMARY}

One of the key prerequisites for introducing sectoral exemptions on the automotive market were the efforts of consumer organisations to limit the decision-making and the influence of manufacturers of the given vehicle brands on the structure of functioning of this market (Rozporządzenie, 2010). The available literature on the transport economics emphasised that this goal was to be achieved by defining specific categories of "spare parts" as elements, which can be used in repair processes of individual vehicles (Koźlak, 2007). Within the assumption that the increased competitiveness was to affect the considerable reduction of total repair costs through the improvement of the market availability. At this stage, it is worth emphasising that the costs of repairing a passenger car are determined by two fundamental factors - the cost of spare parts and the cost of labour. Provided that the analysis of components of repair costs indicates that the share of replacement costs is still meaningful. Certainly, this argument was used by the European Commission, which despite lobbying by automotive companies, in 2010 decided unanimously to extend the duration of the regulation in the unchanged form until 2023.

In today's market reality, the production and sale of new cars does not generate significant profits, given that this process has been highly costly until recently. Only the introduction of technological solutions in recent years in the form of using the floor boards, or propulsion units, in a dozen or so models reverses this unfavourable cost relation. Furthermore, as indicated by the available reports and studies, currently, the profitability from car production is $1 \%$, while it oscillates at 3\% from sales. If we add up to profits obtained from the sale of spare parts in dealership networks, at the level of $9 \%$, the car manufacturer can increase profitability of his activity by up to $13 \%$ (Industry condition 2013) by taking over all these links. This situation is certainly an answer 
to a question why car manufacturers take actions to reduce the number of independent suppliers of spare parts (Analiza i ocena ekonomiczna, 2016). This tendency, so far noticeable only in Western Europe, is being noticed more often on the Polish market of automotive manufacturers. Examples may include lobbying to demonstrate the superiority of original components distributed solely by the vehicle manufacturer over other categories of spare parts. This process is not intended to hinder the customer from accessing other categories of parts, because such behaviour is contrary to the idea of market competitiveness, but it should lead to the generalization of profits of car manufacturers from sales of new components signed with the logo of the given vehicle manufacturer.

On the other hand, the analysis of the combined results of the author's simulations and research allows us to state that:

1. Significant changes were observed in the dynamics of price variation of original spare parts in the analysed time period.

2. The introduction of sectoral exemptions in 2003 led to a significant reduction in the prices of spare parts, in particular in 2004. This trend has been observed for all analysed vehicle manufacturers from the studied market segment.

3. Despite the increase in market availability to other spare parts categories, a systematic price increase has been observed in subsequent years, and the year 2010 had the highest values.

4. Toyota and Peugeot after 2010 decided to gradually increase the prices of spare parts, and their value in 2017 significantly exceeds the price from before the introduction of sectoral exemptions in Poland.

5. While in the case of Fiat and Skoda, a significant reduction in prices of spare parts was observed from 2010 to 2017.

6. Moreover, the author's research has shown that the view promoted in the available literature of the subject is not fully reflected in the modern market reality.

Summing up, the author's attempt to present the economic dimension of the impact of sectoral exemptions on the dynamics of the price variation of original spare parts for passenger cars in Poland does not fully exhaust the essence of the issue, but is merely an attempt to signal the complexity of the studied issue concerning the relevance of the EU regulations relating to the automotive market, and it certainly requires further analyses and studies in order to understand the processes that shape the demand and supply on the market of original spare parts in Poland.

\section{BIBLIOGRAPHY}

Abramek, M. Uzdowski, F. (2012). Pojazdy Samochodowe Podstawy obsługiwania i napraw. Warszawa: Wydawca Wydawnictwa Komunikacji i Łączności.

Analiza i ocena ekonomiczna krajowego rynku samochodów osobowych (2016). Warszawa: PZPM.

Burnewicz, J. (2005). Sektor samochodowy Unii Europejskiej. Warszawa: Wydawnictwa Komunikacji i Łączności.

Burda, M., Wyplosz, Ch. (2013). Makroekonomia. Podręcznik europejski. Warszawa: PWE.

Colino, S.M. (2010). Recent Changes in the Regulation of Motor Vehicle Distribution in Europe - Questioning the Logic of Sector-Specific Rules for the Car Industry. Competition Law Review, 6 (2), 203-224.

Commission Regulation (EC) No. 1400/2002 of 31 July 2002 (2002) on the Application of Article 81(3) of the Treaty to Categories of Vertical Agreements and Concerted Practices in the Motor Vehicle Sector OJ L 203, 1.8.2002.

Creutzig, J. (2003). EG-Gruppenfreistellungs-Verordnung (GVO) für den Kraftfahrzeugsektor. Heidelberg-Berlin: Verlag Recht und Wirtschaft GmbH. 
Instrukcja programu Eurotax (2017). Warszawa.

Kaliszuk, E., Ambroziak Ł., Błaszuk-Zawiła M., Kozłowski Z. (2011). Zmiany konkurencyjności przemysłu motoryzacyjnego Czech, Polski, Stowacji $i$ Wegier w latach 2000-2009. Warszawa: IBKiK.

Koźlak, A. (2007). Ekonomika transportu. Teoria i praktyka gospodarcza. Gdańsk: Wydawnictwo Uniwersytetu Gdańskiego.

Lewicki, W. (2014). Ekonomiczne skutki wyłączeń sektorowych na rynku motoryzacyjnym w Polsce - analiza kosztów napraw samochodów osobowych. Folia Pomeranae Universitatis Technologiae Stetinensis seria OECONOMICA, 76, $73-78$.

Nowak, J. (2004). Bezpieczeństwo samochodów i ruchu drogowego. Warszawa: Wydawnictwa Komunikacji i Łączności.

Rozporządzenie Rady Ministrów z dnia 8 października 2010 r. w sprawie wyłączenia określonych porozumień wertykalnych w sektorze pojazdów samochodowych spod zakazu porozumień ograniczających konkurencję. Dz.U. 2010, nr 198, poz. 1315.

Sprzedaż samochodów osobowych i dostawczych (2017). Warszawa: PZPM.

Stan branży motoryzacyjnej oraz jej rola w polskiej gospodarce (2013). Warszawa: KPMG.

Szymonik, A. (2013). Ekonomika transportu dla potrzeb logistyka. Teoria i praktyka. Warszawa: Difin.

Zieliński, A (2008). Konstrukcja nadwozi samochodów osobowych i pochodnych. Warszawa: Wydawnictwa Komunikacji i Łączności.

Zucke, S., De Stefano, G. (2010). EC Motor Vehicle Block Exemption Reform: Are You Ready for the New Regime? European Competition Law Review, 3, 93-97.

\section{WYMIAR EKONOMICZNY WPŁYWU WYŁACCZEŃ SEKTOROWYCH NA DYNAMIKĘ ZRÓŻNICOWANIA CEN ORYGINALNYCH CZĘŚCI ZAMIENNYCH DO POJAZDÓW SILNIKOWYCH W POLSCE}

STRESZCZENIE

SŁOWA KLUCZOWE
W artykule zaprezentowano rozważania dotyczące wpływu regulacji prawnych w postaci wyłączeń sektorowych na dynamikę zróżnicowania cen oryginalnych części zamiennych do pojazdów silnikowych w Polsce. W celu zaprezentowania wymiaru ekonomicznego podjętej problematyki badawczej posłużono się studium przypadku - eksperymentem numerycznym, polegającym na analizie zmian cen ściśle wyselekcjonowanych części zamiennych od momentu prowadzenia wspomnianych regulacji prawnych aż do 2017 roku. Zamierzeniem artykułu jest zwrócenie uwagi na istotę podjętej problematyki badawczej poprzez wykazanie, że wprowadzenie regulacji unijnych w postaci wyłączeń sektorowych, pomimo poprawy konkurencyjności rynkowej w postaci wzrostu dostępności do innych kategorii części zamiennych w większości przypadków, nie doprowadziło do znacznej obniżki cen nowych oryginalnych komponentów na rynku części zamiennych w Polsce. ekonomika transportu, polityka transportowa, wyłączenia sektorowe, ceny części zamiennych, koszty napraw, eksploatacja 